\title{
PENGEMBANGAN VIDEO ANIMASI TUTORIAL UJIAN TANDA KECAKAPAN KHUSUS PRAMUKA SEKOLAH DASAR
}

\author{
Hendar Ahmad Wibisono ${ }^{1}$, Robinson Situmorang ${ }^{2}$, Etin Solihatin ${ }^{3}$ \\ e-mail: ahmad_hendar@yahoo.com ${ }^{1}$, rsitumorang@unj.ac.id ${ }^{2}$, \\ etin_solihatin@unj.ac.id ${ }^{3}$ \\ Program Magister Teknologi Pendidikan, Universitas Negeri Jakarta \\ Jalan Rawamangun Muka Raya, RT.11/RW.14, Rawamangun, Kec. Pulo Gadung, Kota Jakarta \\ Timur, Daerah Khusus Ibukota Jakarta 13220
}

\begin{abstract}
Abstrak: Minimnya media instruksional sebagai salah satu sumber belajar materi kepramukaan di sekolah, menjadi latar belakang dilakukannya penelitian ini. Penelitian pengembangan ini bertujuan untuk mengembangkan media pembelajaran video animasi tutorial ujian Tanda Kecakapan Khusus (TKK) wajib pramuka tingkat penggalang, sebagai salah satu sumber belajar dalam ujian TKK wajib dalam kegiatan kepramukaan. Model metode pengembangan yang digunakan adalah model pengembangan ADDIE. Penelitian pengembangan ini menghasilkan sebuah media pembelajaran Video Animasi Tutorial Ujian TKK Wajib Pramuka dalam bentuk video animasi .mp4 yang dapat dioperasikan pada perangkat keras yang memiliki fitur pemutar media digital, seperti; smartphone dan notebook. Video animasi tutorial ini juga disertai buku pedoman penyelenggaran dan Lembar Kerja Siswa (LKS) sebagai pelengkap produk media instruksional. Pada tahap pengembangan, video animasi tutorial ini telah diuji oleh ahli materi yang memiliki kualifikasi di bidang kepramukaan dan ahli media, dengan hasil "baik". Adapun dalam tahap implementasi dan evaluasi, video animasi tutorial ini telah diuji oleh praktisi pembelajaran dan pengguna, hasilnya adalah video animasi tutorial dapat menjadi acuan dalam kegiatan kepramukaan untuk penyelenggaraan ujian TKK wajib tingkat penggalang yang dibuktikan dengan adanya peningkatan nilai pada saat tes awal dibandingkan dengan nilai pada saat tes akhir dalam asesmen kegiatan kepramukaan.
\end{abstract}

Kata-kata Kunci: ADDIE, pramuka, tanda kecakapan khusus, video animasi, video tutorial

\section{DEVELOPING ANIMATED VIDEO TUTORIAL OF ADVANCEMENT BADGES SCOUTING TEST FOR PRIMARY SCHOOL}

\begin{abstract}
The lack of instructional media as scouting material learning resources in schools become the reason in conducting this research. This study aims to develop an animated video tutorial of advancement badges test for boyscout, as one of learning resources for scouting. The development model method used was ADDIE. This research produced an animated video tutorial of advancement badges test for boyscout in .mp4 video format which can be operated on hardware that has a player feature, such as; smartphone and notebook. This animated video tutorial is accompanied by a manual book and student worksheet as a complementary to instructional media products. At step of development, This animated video tutorial has been tested by qualified material and media experts of scouting, which results "good". As for the implementation and evaluation stages, this video has been tested by learning practition and users. The result from this stage recommends that the animated video tutorial can be used as a reference for advancement badges test for boyscout. It was proven by an increasing score at the time of the pretest compared to the score at the end of posttest assessment of scouting activities.
\end{abstract}

Keywords: ADDIE, advancement badges, animated video, scouting, tutorial video 


\section{PENDAHULUAN}

Pernyataan yang terkandung dalam UU SISDIKNAS No. 20 tahun 2003 menegaskan bahwa pendidikan tidak hanya mengejar suatu nilai yang tertulis, namun juga sebuah 'nilai' (value) tentang karakter, hardskill, maupun softskill. Pembelajaran yang sangat dibutuhkan dalam kurikulum 2013 ini tentunya tidak hanya mengedepankan aspek kognitif saja, terdapat 4 aspek penting yang harus diterapkan, yaitu; Penguatan Pendidikan Karakter (PPK), Literasi, Creative, Critical Thinking, Communicative, dan Collaborative (4C), dan High Order Thinking Skill (HOTS).

Kurikulum 2013 menjadikan pendidikan kepramukaan menjadi sebuah kegiatan ekstrakurikuler wajib, hal ini karena pramuka dapat menjadi salah satu penguatan pendidikan karakter. Kenyataan di lapangan bahwa kegiatan pramuka memiliki beberapa kendala yang sering ditemukan, diantaranya adalah ketika pembina menyampaikan materi teknis yang sulit dipahami oleh siswa secara maksimal. Sebabnya adalah keterbatasan media pembelajaran yang digunakan oleh pembina dalam menyampaikan, pembina menyampaikan hanya dengan bahasa tubuh.

Kegiatan pembelajaran yang dilakukan diluar jam sekolah seperti kegiatan ekstrakurikuler adalah sebuah program instruksional yang alokasi waktunya tidak ditetapkan secara baku dalam kurikulum sekolah maupun kurikulum nasional. Kegiatan ekstrakurikuler adalah salah satu perangkat operasional kurikulum yang harus disusun dan dibakukan dalam sebuah rencana kerja yang tentunya mengacu kepada kalender pendidikan sekolah.

Menurut Damanik (2014) kegiatan ekstrakurikuler menjembatani kebutuhan perkembangan siswa yang berbeda; seperti perbedaan rasa akan moral dan sikap (Damanik, 2014). Hal ini tentu akan menjadi sebuah langkah kegiatan pembelajaran yang bersifat pengalaman langsung dari akumulasi teori pada setiap mata pelajaran yang mereka pelajari di kelas.

Peraturan Menteri Pendidikan dan Kebudayaan Republik Indonesia 81A tentang Implementasi Kurikulum 2013 pada lampiran III mengatakan bahwa kegiatan ekstrakurikuler merupakan salah satu perangkat operasional kurikulum yang perlu disusun serta dituangkan dalam sebuah kalender akademik pendidikan. Kegiatan ekstrakurikuler sekolah adalah suatu entitas kegiatan yang tidak dapat dipisahkan dari kegiatan intrakurikuler sekolah, seperti mata pelajaran wajib, muatan lokal, mata pelajaran tambahan seperti;
(1) agama, (2) seni, (3) tari, dan yang lainnya.

Diantara banyaknya kegiatan ekstrakurikuler yang dapat menguatkan pendidikan karakter, kurikulum 2013 menjadikan pendidikan kepramukaan menjadi sebuah kegiatan ekstrakurikuler wajib pada satuan pendidikan mulai dari SD hingga SMA, bahkan ada beberapa sekolah yang menjadikan pendidikan kepramukan menjadi pelajaran kepramukaan. Dalam aspek penilaian kurikulum 2013 yang terdiri dari 4 Kompetensi Inti (KI), kegiatan pendidikan kepramukaan dapat menjadi acuan penilaian dari aspek sikap sosial (KI-2) dan sikap keterampilan (KI-4) meskipun aspek sikap spiritual (KI-1) serta pengetahuan (KI-3) juga dapat dilakukan melalui implementasi dari trisatya dan dasadarma pramuka. Undang-Undang Gerakan Pramuka No.12 tahun 2010 menjelaskan bahwa Gerakan Pramuka bertujuan untuk meningkatkan setiap anggotanya agar memiliki kepribadian yang beriman, bertakwa, serta berakhlak mulia, berjiwa patriotik, taat hukum, disiplin, dan mencintai tanah air sebagai Negara Kesatuan Republik Indonesia.

Salah satu kegiatan dalam pramuka adalah ujian tanda kecakapan khusus (TKK) yang tentu saja memiliki beberapa aspek baik dalam kognitif dan psikomotorik. Video pembelajaran adalah sebuah gambar bergerak yang disusun dari kumpulan beberapa objek yang disusun secara khusus yang dirancang untuk memenuhi tujuan pembelajaran.

Menurut Smaldino (2011) dalam Instructional Technology and Media for Learning mengatakan bahwa sebuah format media merupakan bentuk fisik dari yang didalamnya terdapat pesan yang disertakan dan ditampilkan (Smaldino, 2011).

Berdasarkan beberapa paparan ahli tentang media dan pembelajaran di atas dapat disimpulkan bahwa media pembelajaran adalah media yang dirancang khusus untuk sebuah tujuan instruksional yang telah ditetapkan oleh perancang media, selain itu media pembelajaran mampu mengadirkan sesuatu yang rumit dan berbahaya dalam ruangan kelas.

Media pembelajaran ditinjau dari kegunaannya terdapat dua jenis, yaitu; media by design adalah media pembelajaran yang sengaja dirancang dan dibuat khsusus untuk tujuan instruksional tertentu yang mengacu kepada kompetensi dan GBIM (Garis Besar Isi Media) yang sudah ditentukan sebelumnya. Adapun beberapa contoh media by design adalah; buku paket, modul belajar, video pembelajaran, buku kurikulum, dan media lainnya. Adapun media by utilization adalah media pembelajaran yang sudah ada dan dapat dimanfaatkan sebagai salah satu sumber 
belajar. Media by utilization tidak dirancang khusus untuk tujuan instruksional sebagai contoh media by utilization adalah; sawah, tempat bersejarah, dokter sebagai narasumber, dan media lainnya yang memiliki relevansi dengan pembelajaran.

Menurut Arsyad Azhar (2009) dalam Media Pembelajaran ada delapan jenis media pembelajaran, yaitu; (1) media cetak, (2) media pajang, (3) overhead transparancies (OHP), (4) tape recorder, (5) slide show dan filmstrips, (6) penyajian multi-image, (7) rekaman video dan film, (8) komputer (Arsyad, 2009).

Dalam kegiatan pramuka Tanda Kecakapan Khsus (TKK) adalah tanda yang menunjukan kecakapan, ketangkasan, keterampilan, serta kemampuan sikap setiap anggota pramuka di bidang yang tertera pada setiap tanda tersebut, yang mana tanda kecakapan khusus tersebut merupakan sebuah penghargaan bagi anggota pramuka yang telah berhasil menyelesaikan ujian untuk mendapatkan tanda kecakapan khusus tersebut. Untuk lebih jelas terkait TKK pramuka, maka berikut ini akan dikaji terlebih dahulu terkait TKK dan cara mendapatkannya.

Tanda Kecakapan Khsusus (TKK) sebagai alat pendidikan dalam kegiatan kepramukaan dimana hal ini menjadi sebuah motivasi intrinsik dalam pramuka untuk memperoleh kecakapan yang nantinya berguna bagi kehidupan. Dalam memperoleh TKK tentu saja ada beberapa syarat yang harus dipenuhi yang disebut dengan Syarat Kecakapan Khusus (SKK), dengan demikian setiap individu dapat mengembangkan kemampuan serta keterampilannya sesuai dengan minat dan bakatnya masing-masing.

Diantara banyaknya TKK tentu saja ada sepuluh TKK wajib yang harus didapatkan oleh setiap anggota pramuka, menurut panduan kursus mahir pembina tingkat dasar yang diterbitkan oleh Kawartir Nasional Gerakan Pramuka (Kwarnas) tahun 2014 ada sepuluh Tanda Kecakapan Khusus yang harus dimiliki oleh setiap anggota pramuka tingkat penggalang, diantaranya; (1) berkemah, (2) pertolongan pertama pada kecelakaan, (3) juru kebun, (4) juru masak, (5) pengamanan kampung, (6) pengamat, (7) penabung, (8) gerak jalan, (9) pengatur rumah, dan (10) penjahit (Kwarnas, 2014).

Dalam penelitian pengembangan pembuatan pengembangan video animasi tutorial ujian TKK wajib pramuka penggalang sekolah Islam terpadu Ibnu Hajar Mandiri peneliti mengkaji beberapa sumber penelitian sebelumnya yang relevan, baik yang memiliki relevansi dalam bidang kepramukaan, pengembangan modul, pendidikan karakter, maupun semuanya (Hanafri et al., 2018).
Diantara relevansi penelitian ini diantaranta adalah penelitian yang dilakukan oleh Arianto (2017) dengan tema penelitian "Scout Learning Sebagai Media Interaktif Pembelajaran Pramuka Berbasis Multimedia". Fokus dari penelitian ini adalah mengembangkan sebuah media bebasis mobile application yang dapat dioperasikan dengan perangkat smartphone. Adapun tujuan dari penelitian ini adalah bagaimana mengembangkan multimedia yang dapat diakses oleh siswa untuk memenuhi kebutuhan pembelajaran pramuka (Wahyuni \& Arianto, 2017).

Relevansi antara beberapa penelitian sebelumnya dengan penelitian yang peneliti lakukan juga serupa dengan Arifin (2013) dengan judul penelitian "Pengembangan Multimedia Interaktif Materi Sandi Morse dalam Kegiatan Ekstrakurikuler Kepramukaan bagi Siswa Kelas V'. Implikasi dari penelitian ini berupa pengembangan multimedia interaktif untuk sub pembelahjaran sandi morse dalam kegiatan pramuka siswa kelas V SD berbasis aplikasi Adobe Flash Player yang berbasis komputer (Arifin et al., 2013).

Penelitian yang memiliki relevansi selanjutnya adalah penelitian pengembangan video animasi berbasis Flash Player yang dilakukan oleh Khasanah (2013) dengan judul penelitian "Media Pembelajaran Pramuka Berbasis Multimedia”. Dengan latar belakang penelitian kurangnya media pembelajaran dalam materi pramuka. Jenis penelitian pengembangan yang dilakukan adalah penelitian pengembangan berupa pembuatan video animasi. (Khasanah, 2013)

Lebih lanjut revelansi penelitian yang peneliti lakukan sejalan dengan penelitian pengembangan video animasi yang dilakukan oleh Anwar (2018) dengan judul penelitian "Pengembangan Media Autoplay Berbasis Video Animasi pada Materi Kenampakan Alam dan Sosial Budaya Siswa Kelas IV SDN Ponggok 1 Blitar". Latar belakang penelitian ini adalah kurang menarik materi pembelajaran pada IPS ketampakan alam bagi siswa. Jenis penelitian pengembangan yang dilakukan adalah penelitian pengembangan berupa pembuatan video animasi dengan desain pembelajaran model ADDIE. (Anwar, 2018).

Berdasarkan beberapa penelitian sebelumnya yang memliki relevansi dengan tema penelitian yang peneliti lakukan dapat disimpulkan bahwa ketiga variabel pengembangan video animasi, pembelajaran, serta keterampilan memiliki keterkaitan yang dapat dikembangkan menjadi sebuah produk instruksional yang nantinya dapat di implementasikan dalam kegiatan pembelajaran maupun ekstrakurikuler 
pramuka penggalang pada tingkat sekolah dasar. Hal ini tentu saja selaras dengan program penguatan karakter yang sedang gencar dicanangkan oleh pemerintah dalam rangka menemukan, menggali, serta mengembangkan potensi dan bakat siswa. Di samping itu kegiatan ekstrakurikuler Pramuka dapat memfasilitasi bakat, minat, dan kreativitas peserta didik yang berbeda-beda (Kemendikbud, 2014).

Fokus penelitian ini adalah bagaimana mengembangkan video animasi tutorial ujian TKK pramuka untuk dapat diterapkan dalam kegiatan ujian pramuka. Diharapkan dengan adanya pengembangan video pembelajaran ujian TKK pramuka ini dapat menjadi salah satu solusi dalam memecahkan permasalahan tersebut.

Tujuan dan signifikasi dari penelitian yang peneliti lakukan adalah untuk mengembangkan video animasi tutorial ujian TKK berkemah pramuka tingkat penggalang untuk dapat digunakan dalam kegiatan ekstrakurikuler pada satuan sekolah Islam terpadu. Diharapkan dengan adanya video animasi tutorial ujian TKK berkemah pramuka tingkat penggalang ini kegiatan pelaksanaan ujian TKK dalam ekstrakurikuler pramuka di sekolah Islam terpadu dapat menjadi lebih efektif.

State of the art atau keterbaruan penelitian ini berupa pengembangan sebuah video animasi tutorial ujian TKK wajib pramuka penggalang, dimana ujian TKK merupakan salah satu teknik kepramukaan yang menjadi kegiatan wajib pada setiap gugusdepannya. Lebih lanjut keterbaruan penelitian pengembangan yang peneliti kembangkan adalah video animasi tutorial yang dapat ditonton pada perangkat komputer, notebook, maupun smartphone sehingga siswa dapat menjadikan video animasi tutorial ini sebagai acuan belajar mandiri dalam kegiatan pramuka.

\section{METODE PENELITIAN}

Diantara lima jenis kawasan penelitian dalam Teknologi Pendidikan sebagaimana yang dikemukakan oleh Barbara B. Seels dan Rita C. Richey (1994) dalam sebuah definisi AECT (Association for Educational Communications and Technology) tahun 1994 bahwa kawasan Teknologi Pendidikan meliputi lima kawasan, diantaranya; (1) kawasan desain (design), (2) kawasan pengembangan (development), (3) kawasan pemanfaatan (utilization), (4) kawasan pengelolaan (management), (5) kawasan penilaian (evaluation). (Seels, 1994)

Jenis desain ini merupakan penelitian pengembangan (Research and Development). Model pengembangan yang digunakan dalam pengembangan video pembelajaran animasi tutorial ini adalah ADDIE. Penelitian yang peneliti lakukan pada awal tahun ajaran 2019/2020 bertempat di SD Islam Ibnu Hajar Mandiri Bekasi, penelitian ini dilakukan selama satu tahun ajaran pada kegiatan pramuka setiap pekannya dengan durasi pelaksanaan kegiatan pramuka $2 \times 60$ menit.

Penelitian yang peneliti lakukan akan dilaksanakan pada awal tahun ajaran 2019/2020 pada gugus depan SD Islam Ibnu Hajar Mandiri Bekasi, penelitian ini dilakukan selama satu tahun ajaran setiap hari Kamis pada kegiatan ekstrakurikuler pramuka setiap pekannya dengan durasi pelaksanaan kegiatan pramuka 2 × 60 menit. Peneliti melihat adanya kebutuhan dalam pembuatan dan pengembangan video animasi tutorial ujian TKK wajib ekstrakurikuler pramuka dalam pelaksanaan ujian TKK wajib dalam kegiatan pramuka, selain belum adanya video animasi tutorial ujian TKK dalam pelaksanaan kegiatan ekstrakurikuler pramuka, video tutorial ujian TKK yang akan dibuat diharapkan akan mempermudah anggota yang akan melaksanakan ujian TKK wajib.

Jenis desain penelitian yang peneliti lakukan adalah jenis penelitian Research and Development (R\&D). Diantara banyaknya model dan teori tentang jenis penelitian pengembangan modul, peneliti merujuk kepada model pengembangan ADDIE (Analysis, Design, Development, Implementation, Evaluation) (Branch, 2009). Tahapan dalam penelitian pengembangan model ADDIE adalah sebagai berikut.

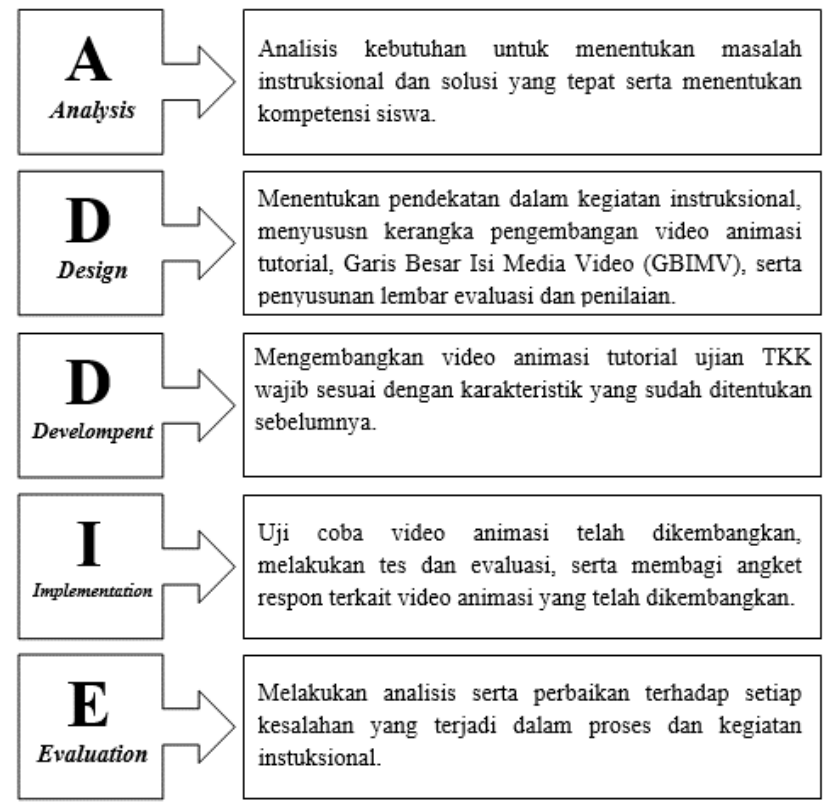

Gambar 1. Rancangan desain penelitian pengembangan model ADDIE. 
Dalam penelitian pengembangan ini, instrumen penelitian yang dipakai dalam pengumpulan data adalah wawancara, kuesioner, observasi, evaluasi, serta dokumentasi. Instrumen kuesioner dalam penelitian ini dibuat dalam kuesioner tertutup dengan skala bertingkat (skala likert). Skala likert lazim digunakan dalam membandingkan efektivitas pengembangan modul cetak pramuka tingkat penggalang yang berbasis karakter. Kuesioner digunakan untuk melihat keefektifan modul. Selanjutnya, instrumen dokumentasi dalam penelitian ini adalah check list. Adapun dokumentasi digunakan untuk melihat data hasil pretest dan posttest modul cetak pramuka penggalang berbasis karakter. Berikut ini adalah tabel instrumen yang digunakan pada setiap fase dalam penelitian ini.

Tabel 1.

Instrumen di Setiap Fase

\begin{tabular}{|c|c|c|}
\hline Fase & Fokus & Instrumen \\
\hline Analisis & $\begin{array}{l}\text { Analisis } \\
\text { Kebutuhan } \\
\text { Teori }\end{array}$ & $\begin{array}{l}\text { Kuesioner Pra- } \\
\text { Penelitian }\end{array}$ \\
\hline Pengembangan & Validasi Pakar & $\begin{array}{l}\text { Angket } \\
\text { Penilaian Pakar }\end{array}$ \\
\hline Implementasi & a. Praktikalitas & $\begin{array}{l}\text { Angket } \\
\text { Responden }\end{array}$ \\
\hline \multirow{3}{*}{ Evaluasi } & b. Efektifitas & Tes \\
\hline & $\begin{array}{l}\text { a. Evaluasi } \\
\text { Formatif }\end{array}$ & $\begin{array}{l}\text { Lembar } \\
\text { Observasi }\end{array}$ \\
\hline & $\begin{array}{l}\text { b. Evaluasi } \\
\text { Summatif }\end{array}$ & Tes \\
\hline
\end{tabular}

Arikunto (2014) mengatakan subjek penelitian adalah suatu variabel penelitian yang mana merupakan inti dari problematika penelitian (Arikunto, 2014). Subjek penelitian yang diteliti oleh peneliti adalah pengembangan modul cetak pendidikan kepramukaan berbasis karakter tingkat penggalang Sekolah Dasar Islam Terpadu Ibnu Hajar Mandiri. Subjek penelitian ini adalah anggota pramuka penggalang kelas V-B yang berjumlah 32 orang.

Uji coba instrumen dilakukan di Sekolah Dasar Islam Terpadu Ibnu Hajar Mandiri Bekasi. Aspek penilaian pakar berupa kesesuaian angket dengan indikator yang ada, kesesuaian soal tes dengan modul, tata bahasa, serta penggunaan kalimat pada setiap pernyataan yang ada pada angket dan pertanyaan pada modul yang telah tersedia.

Proses penelitian diawali dengan pengumpulan data. Pengumpulan data merupakan proses pencarian data yang dilakukan dengan penyebaran kuesioner kepada siswa, observasi, dan dokumentasi. Selanjutnya setelah data dikumpulkan, dilakukan proses reduksi data. Reduksi data merupakan proses seleksi, pemfokusan, penyederhanaan, dan abstraksi data yang ada dalam fields note. Setelah peneliti melakukan pemilahan data, kemudian data dibuat dalam bentuk kalimat naratif, logis, dan sistematis yang mengacu pada rumusan masalah. Tahap akhir adalah kesimpulan atau verifikasi data. Fase pada tahap akhir adalah membuat kesimpulan atas hasil atau konfigurasi. Hasil kesimpulan harus diverifikasi ulang untuk mengembangkan keakuratan hasil penelitian.

Adapun instrumen penelitian dan tahap pengembangan produk berupa video animasi tutorial penulis jabarkan pada langkah-langkah berikut.

Tahap pengembangan video yang sudah dirancang sesuai dengan analisis kebutuhan instruksional. Dalam hal mengembangkan video animasi tutorial ujian TKK wajib kegiatan pramuka penggalang pada SDIT Ibnu Hajar Mandiri Bekasi. Kemudian dalam tahap pasca produksi, peneliti melakukan kajian ahli kepada para ahli yang yang memiliki kompetensi sesuai bidang kajiannya, diantaranya yaitu:

1. Melakukan validasi oleh ahli desain pembelajaran untuk menilai terkait validitas rancangan desain instruksional. Peneliti menunjuk seorang instruktur pembelajaran dari Kemendikbud, bapak Dedy Setyo Afrianto, M. Pd yang memiliki latar belakang pendidikan S2 Teknologi Pendidikan Universitas Sultan Ageng Tirtayasa, Serang.

2. Melakukan validasi oleh ahli materi terkait kepramukaan untuk menilai korelasi konten dalam kegiatan pramuka. Peneliti menunjuk seorang pembina pramuka dari SMAN 9 Bekasi, bapak Tatang Wahyudi, M. Pd yang memiliki latar belakang pendidikan S2 Manajemen Pendidikan Universitas Negeri Jakarta.

3. Melakukan validasi oleh ahli video untuk menilai kesamaan video dengan naskah yang telah dibuat sesuai dengan kaidah video yang baik. Peneliti menunjuk seorang ahli pengembang video dari SMPIT Lughotuna Bekasi, bapak Asri Ben Djali, M. Pd yang memiliki latar belakang pendidikan S2 Teknologi Pendidikan Universitas Negeri Jakarta.

4. Melakukan validasi oleh ahli media untuk menilai kualitas media pembelajaran yang dikembangkan sudah sesuai dengan standar yang baik. Peneliti menunjuk seorang ahli media pembelajaran dari Universitas Pendidikan Indonesia, bapak Dr. Supangat Rohani, M. Pd yang memiliki latar 
belakang pendidikan S3 Pengembangan Kurikulum Universitas Pendidikan Indonesia, Bandung.

5. Membuat kuesioner yang akan dinilai oleh pakar media video animasi tutorial.

Tabel 2.

Kisi-Kisi Kuesioner Pakar Media

\begin{tabular}{clc}
\hline No & Aspek yang Dinilai & Jumlah Item \\
\hline 1. & Content & 3 \\
2. & Video Design & 5 \\
3. & Video Interface & 6 \\
4. & Narrator & 5 \\
\hline
\end{tabular}

Sumber: Eveline Siregar \& Tian Hadiansyah, (2018).

Pedoman Pelaksanaan Evaluasi Media Pembelajaran, hlm. 75.

6. Membuat kuesioner yang akan dinilai oleh pakar materi.

Tabel 3.

Kisi-Kisi Kuesioner Pakar Materi

\begin{tabular}{clc}
\hline No & Aspek yang Dinilai & Jumlah Item \\
\hline 1. & Tujuan Pembelajaran & 3 \\
2. & Tingkat Kedalaman Materi & 2 \\
3. & Penyajian Materi & 3 \\
\hline
\end{tabular}

Sumber: Eveline Siregar \& Tian Hadiansyah, (2018). Pedoman Pelaksanaan Evaluasi Media Pembelajaran, hlm. 77.

7. Membuat kuesioner yang akan dinilai oleh pakar media pembelajaran.

Tabel 4.

Kisi-Kisi Kuesioner Pakar Media Pembelajaran

\begin{tabular}{clc}
\hline No & Aspek yang Dinilai & Jumlah Item \\
\hline 1. & Video Interface & 19 \\
2. & Narrator & 7 \\
3. & Content & 8 \\
\hline
\end{tabular}

Sumber: Eveline Siregar \& Tian Hadiansyah, (2018). Pedoman Pelaksanaan Evaluasi Media Pembelajaran, hlm. 77 .

Setelah dilakukan desain dan pengembangan maka tahap berikutnya adalah tahap implementasi video yang telah dibuat, implementasi dilakukan pada kegiatan ujian TKK wajib pramuka regu penggalang dalam melaksanakan kegiatan pramuka. Kegiatan tes dan evaluasi juga dilakukan dalam rangka mengetahui efektivitas penggunaan video animasi tutorial dengan membagikan angket kepada responden. Kemudian kegiatan ini divalidasi ahli desain pembelajaran yang ditentukan berdasarkan skor pada tabel berikut ini:
Tabel 5.

Nilai Acuan Skoring Media Instruksional

\begin{tabular}{cl}
\hline Skor Presentase & \multicolumn{1}{c}{ Aspek yang Dinilai } \\
\hline $0 \%-24 \%$ & $\begin{array}{l}\text { Sangat Kurang (tidak dapat } \\
\text { dijadikan bahan ajar }\end{array}$ \\
$25 \%-45 \%$ & $\begin{array}{l}\text { Kurang (belum dapat digunakan } \\
\text { sebagai bahan ajar) }\end{array}$ \\
$50 \%-74 \%$ & $\begin{array}{l}\text { Baik (dapat digunakan sebagai } \\
\text { bahan ajar) }\end{array}$ \\
$75 \%-100 \%$ & $\begin{array}{l}\text { Sangat Baik (dapat digunakan } \\
\text { sebagai bahan ajar) }\end{array}$ \\
\hline
\end{tabular}

Lebih lanjut peneliti melakukan asesmen pembelajaran berupa tes pedahuluan untuk mengetahui efektivitas media pembelajaran dalam membantu siswa melaksanakan ujian TKK wajib pramuka tingkat penggalang SDIT Ibnu Hajar Mandiri Bekasi, adapun yang akan diukur dalam asesmen untuk siswa adalah aspek kognitif dengan cara melakukan tes pendahuluan sebelum menggunakan media pembelajaran video animasi tutorial dan tes akhir setelah menggunakan media. Adapun bentuk tes yang dilakukan berupa bentuk kognitif berupa soal berbentuk pilihan ganda dengan kisi-kisi yang mengacu pada tabel di bawah ini:

Tabel 6.

Acuan Evaluasi Kecerdasan Siswa

\begin{tabular}{lcc}
\hline \multicolumn{1}{c}{ Indikator } & $\begin{array}{c}\text { Domain } \\
\text { Kecerdasan }\end{array}$ & Evaluasi \\
\hline $\begin{array}{l}\text { Siswa dapat mengetahui } \\
10 \text { jenis TKK wajib pramu- } \\
\text { ka penggalang. }\end{array}$ & 1,2 & Objektif \\
\hline $\begin{array}{l}\text { Siswa dapat menjelaskan } \\
\text { cara mendapatkan TKK } \\
\text { wajib pramuka berkemah. }\end{array}$ & 3 & Objektif \\
\hline $\begin{array}{l}\text { Siswa dapat menjelaskan } \\
\text { cara mendapatkan TKK }\end{array}$ & 4 & Objektif \\
wajib pramuka gerakjalan. & & \\
\hline $\begin{array}{l}\text { Siswa dapat menjelaskan } \\
\text { cara mendapatkan TKK } \\
\text { wajib pramuka juru ma- } \\
\text { sak. }\end{array}$ & 5 & Objektif \\
\hline $\begin{array}{l}\text { Siswa dapat menjelaskan } \\
\text { cara mendapatkan TKK } \\
\text { wajib pramuka P3K. }\end{array}$ & 6 & Objektif \\
\hline $\begin{array}{l}\text { Siswa dapat menjelaskan } \\
\text { cara mendapatkan TKK } \\
\text { wajib pramuka penabung. }\end{array}$ & 7 & Objektif \\
\hline $\begin{array}{l}\text { Siswa dapat menjelaskan } \\
\text { cara mendapatkan TKK } \\
\text { wajib pramuka juru ke- } \\
\text { bun. }\end{array}$ & 8 & Objektif \\
\hline
\end{tabular}




\begin{tabular}{lcc}
\hline \multicolumn{1}{c}{ Indikator } & $\begin{array}{c}\text { Domain } \\
\text { Kecerdasan }\end{array}$ & Evaluasi \\
\hline $\begin{array}{l}\text { Siswa dapat menjelaskan } \\
\text { cara mendapatkan TKK } \\
\text { wajib pramuka keamanan } \\
\text { kampung. }\end{array}$ & 9 & Objektif \\
\hline $\begin{array}{l}\text { Siswa dapat menjelaskan } \\
\text { cara mendapatkan TKK }\end{array}$ & 10 & Objektif \\
wajib pramuka penjahit. & & \\
\hline $\begin{array}{l}\text { Siswa dapat menjelaskan } \\
\text { cara mendapatkan TKK } \\
\text { wajib pramuka pengatur }\end{array}$ & 11 & Objektif \\
rumah. & & \\
\hline $\begin{array}{l}\text { Siswa dapat menjelaskan } \\
\text { cara mendapatkan TKK } \\
\text { wajib pramuka pengamat. }\end{array}$ & 12 & Objektif \\
\hline $\begin{array}{l}\text { Siswa dapat menyabutkan } \\
\text { jenis-jenis 10 TKK wajib } \\
\text { pramuka penggalang }\end{array}$ & 13,14 & Objektif \\
\hline $\begin{array}{l}\text { Siswa dapat menyebutkan } \\
\text { warna dari 10 TKK wajib } \\
\text { pramuka penggalang }\end{array}$ & 15,16 & Objektif \\
\hline $\begin{array}{l}\text { Siswa dapat menyebutkan } \\
\text { gambar dari 10 TKK wajib } \\
\text { pramuka penggalang }\end{array}$ & 20 & \\
\hline
\end{tabular}

Hasil yang didapatkan dari evaluasi tes pendahuluan dan tes akhir dilakukan penskoran (scoring) yang menjadi acuan dalam ketuntasan pencapaian materi ujian TKK wajib pramuka tingkat penggalang. Adapun yang menjadi acuan dapat dilihat pada tabel dibawah ini:

Tabel 7.

Nilai Acuan Skoring pada Tes Pendahuluan dan Tes Akhir

\begin{tabular}{ccc}
\hline $\begin{array}{c}\text { Soal dan } \\
\text { Bentuk Tes }\end{array}$ & Poin Tiap Soal & Jumlah Poin \\
\hline $1-20$ Objektif & 10 & 200 \\
\hline
\end{tabular}

Nilai Max $\frac{200}{20}=10$

Hasil tes akhir yang dianalisa dengan rumus Uji-t. Analisa yang digunakan untuk menentukan variabel yang terdapat dalam riset terhadap hasil belajar siswa (variabel-X) dan utilisasi media instruksional (variabel-Y). Penilaian ini diolah dengan frekuensi dibagi total reponden kemudian dikalikan 100\% sebagai berikut:

$$
P=\sqrt{\frac{f}{N} \times 100 \%}
$$

Keterangannya adalah sebagai berikut:

$$
\begin{array}{ll}
\mathrm{P} & =\text { presentase } \\
\mathrm{f} & =\text { frekuensi }
\end{array}
$$

$\mathrm{N}=$ total responden

$100 \%=$ total akhir

Adapun perhitungan persentase ini mengikuti beberapa langkah berikut ini:

1. Mengoreksi hasil angket yang diperoleh dari siswa

2. Menghitung frekuensi hasil kuesioner dari siswa

3. Menghitung seluruh jumlah siswa

4. Menghitung hasil kuesioner dengan rumus

Dengan presentase pada setiap katagori:

a) $\frac{\text { Jumlah siswa dengan kategori setuju }}{\text { Jumlah seluruh siswa }} \times 100 \%$

b) $\frac{\text { Jumlah siswa dengan kategori netral }}{\text { Jumlah seluruh siswa }} \times 100 \%$

c) $\frac{\text { Jumlah siswa dengan kategori tidak setuju }}{\text { Jumlah seluruh siswa }} \times 100 \%$

Kemudian peneliti melakukan uji $\mathrm{t}$ untuk mendapatkan kesimpulan terkait penggunaan media video animasi tutorial memberikan sebuah pengaruh untuk hasil ujian TKK wajib pramuka tingkat penggalang SDIT Ibnu Hajar Mandiri Bekasi. Uji t yang dilakukan dengan menentukan taraf rill dan nilai pada rincian berikut ini.

a) taraf riil $\alpha=0,05$

b) uji dua sisi

c) derajat kebebasan $\mathrm{df}=\mathrm{n}-1$

Cara menghitung t adalah dengan memasukan sebuah rumus:

$$
t_{\text {hit }}=\frac{\frac{\bar{D}}{S D}}{\sqrt{n}}
$$

Keterangannya adalah sebagai berikut:

$$
\begin{array}{ll}
\mathrm{n} & =\text { jumlah data } \\
\mathrm{D} & =\text { deviasi } \\
\mathrm{SD} & =\text { Standar Deviasi } \\
\mathrm{y} & =\text { data hasil dari tes pendahuluan } \\
\mathrm{x} & =\text { data hasil dari tes akhir }
\end{array}
$$

\section{HASIL DAN PEMBAHASAN}

\section{Hasil}

Analisis kebutuhan dilakukan dengan cara mengidentifikasi kondisi ideal dan kondisi yang ada saat penelitian dilakukan. Penjelasan yang terkait dengan analisis kebutuhan adalah sebagai berikut:

\section{Keadaan Ideal yang Dikehendaki}

Tahapan awal pada analisis kebutuhan adalah mengetahui keadaan ideal yang seharusnya 
terjadi, hal ini bertujuan untuk mengetahui kompetensi apa yang seharusnya tercapai dalam kegiatan ujian TKK wajib pramuka penggalang SDIT Ibnu Hajar Mandiri. Peneliti melakukan studi dokumen terhadap kurikulum pramuka yang diterapkan, lalu mengidentifikasi silabus kegiatan pramuka yang digunakan dalam kegiatan pramuka pada gugus depan.

Studi dokumen yang telah dilakukan oleh peneliti menunjukkan data bahwa kegiatan ujian TKK wajib pramuka penggalang yang dilaksanakan setiap pekannya 1 kali pertemuan dengan durasi pertemuan 2x45 menit. Kegiatan ujian TKK wajib dalam ekstrakurikuler pramuka memiliki tujuan pembelajaran agar peserta didik dapat mengetahui dan menerapkan 10 macam TKK wajib .

\section{Keadaan Saat Penelitian Dilakukan}

Saat pengembangan produk akan dilakukan, peneliti melakukan analisis dengan menggunakan metode survei serta wawancara terhadap peserta didik, pembina pramuka dan juga kepala sekolah. Analisis yang peneliti lakukan dalam memperoleh informasi terkait proses kegiatan ujian TKK wajib dalam ekstrakurikuler pramuka yang selama ini berlangsung, pencapaian kompetensi, serta kendala atau masalah terkait pembinaan dalam kegiatan kepramukaan.

Kegiatan ujian TKK wajib dalam kepramukaan tingkat penggalang di SDIT Ibnu Hajar Mandiri Bekasi menurut informasi yang diperoleh peneliti adalah kegiatan kepramukaan dalam ekstrakurikuler peserta didik dilakukan praktik lapangan tanpa memiliki acuan visual yang jelas dan hanya dipandu dengan kakak pembina menggunakan pengeras suara.

Pencapaian kompetensi yang diharapkan dalam ujian TKK wajib tingkat penggalang di SDIT Ibnu Hajar Mandiri Bekasi menurut informasi yang diperoleh peneliti adalah untuk pencapaian kompetensi kognitif, afektif, dan psikomotorik siswa melakukan kegiatan sesuai acuan dalam ujian TKK wajib setiap poinnya. Pencapaian kompetensi secara holistik yang diharapkan diperoleh dari tes praktik ketiga aspek tersebut dalam ujian TKK wajib kepramukaan yang dilakukan baik secara individu dan kelompok.

\section{Hasil Perancangan (Design)}

Menurut Sugiyono (2017) penelitian pengembangan memiliki beberapa tahapan, yaitu; 1) potensi dan masalah, 2) pengumpulan data, 3) desain produk, 4) validasi desain, 5) revisi desain,
6) uji coba produk, 7) revisi produk, 8) uji coba pemakaian, 9) revisi produk, dan 10) produksi massal. Adapun jenis desain penelitian yang peneliti lakukan adalah jenis penelitian Research and Development (R\&D). Adapun jenis model pengembangan modul peneliti merujuk kepada model pengembangan ADDIE. Pada tahap awal perancangan, peneliti melakukan beberapa hal, diantaranya; (a) Rancangan awal video animasi tutorial, (b) GBIM, flowchart, sinopsis, naskah, dan story board, (c) Instrumen validasi ahli materi, (d) Instrumen validasi ahli media, (e) Instrumen validasi instruksional.

\section{Hasil Desain dan Pengembangan Produk}

Sesuai dengan tahap awal dalam desain pengembangan model ADDIE, peneliti melanjutkan pada tahap berikutnya yaitu mendesain dan mengembangkan produk instruksional berupa video animasi tutorial ujian TKK wajib kepramukaan untuk tingkat penggalang. Adapun tahap desain dan pengembangan yang peneliti lakukan adalah sebagai berikut.

\section{a. Tahap Desain}

Tahap desain video animasi tutorial ini peneliti melakukan beberapa aspek yang perlu ditampilkan dalam video, diantaranya; (1) tujuan instruksinoal umum yang diperlukan, (2) tujuan instuksional khusus, (3) materi dan bahan ajar yang akan divisualisaikan, (4) garis besar isi media (GBIM), (5) story-board.

\section{b. Tahap Pengembangan Pra-Produksi}

Tahap yang peneliti lakukan pada tahap ini adalah (a) membuat jadwal kegiatan pengembangan, implementasi, dan evaluasi produk secara keseluruhan, (b) menunjuk tim produksi, (c) menentukan tim ahli dalam kepramukaan, (d) melakukan persiapan perangkat yang diperlukan dalam menyusun video, seperti laptop, harddisk, perangkat lunak, dan yang lainnya, (e) menentukan konsep kepada tim pengembang. Nama dan jumlah anggota tim produksi dapat dilihat pada lembar lampiran penelitian ini.

\section{c. Tahap Pengembangan Produksi}

Tahap produksi adalah tahap dimana peneliti melakukan pengembangan video animasi tutorial ujian TKK wajib tingkat penggalang kepramukaan. Pada tahap ini peneliti bekerja sama dengan tim produksi melakukan (a) membuat video animasi tutorial berdasarkan GBIM yang telah peneliti 
rumuskan sebelumnya, (b) membuat animasi tokoh seorang kakak pembina pramuka, (c) dubbing dengan suara peneliti, (d) editing, (e) mixing, (f) rendering, (g) review secara internal, (h) editing ulang, (i) mixing ulang, (j) rendering ulang, (k) menghasilkan produk purwarupa video animasi tutorial, (l) duplicating pasca revisi oleh ahli media.

\section{d. Tahap Pengembangan Pasca-Produksi}

Tahap pasca produksi adalah tahap dimana peneliti melakukan uji validitas materi oleh ahli materi kepramukaan dan uji validasi media oleh ahli media serta peneliti melakukan revisi produk pada tahap akhir.

Hasil dari video animasi tutorial ujian TKK wajib kepramukaan divalidasi oleh beberapa ahli diantaranya ahli materi oleh Tatang Wahyudi, M.Pd, ahli media oleh Dr. Supangat Rohani, M.Pd. instrumen yang digunakan sebagai bahan penilaian ahli sebelumnya telah divalidasi oleh Dedy Setyo Afrianto, M.Pd.

Hasil pretest yang dlakukan pada aspek kognitif berupa butir soal sebanyak 32 butir soal yang mengacu kepada kompetensi dasar 10 TKK wajib kepramukaan. Kegiatan pretest dimaksudkan untuk mengetahui tingkat pencapaian hasil kognitif siswa SDIT Ibnu Hajar Mandiri Bekasi pada kegiatan ujian TKK wajib kepramukaan. Dari kegiatan pra siklus ini ditemukan hasil evaluasi pembelajaran siswa digambarkan dalam diagram berikut.

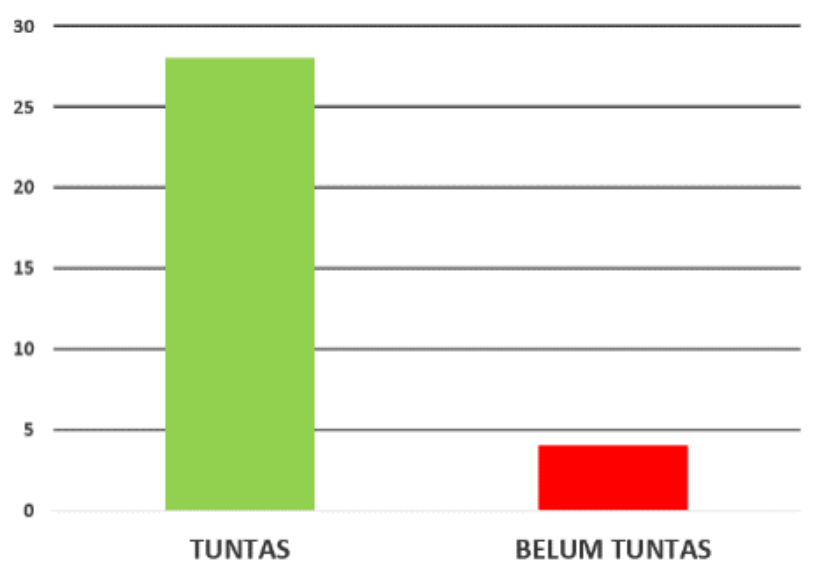

Gambar 2. Diagram Ketuntasan Nilai Pre-Test Aspek Kognitif Ujian Pramuka.

Setelah siswa mengerjakan pretest, siswa disajikan kegiatan pramuka dengan video animasi tutorial yang telah disiapkan sebelumnya dalam ruangan aula. Setelah kegiatan menonton video selesai, siswa kembali diberikan soal posttest sebanyak 20 soal yang sama seperti pretest yang mengukur aspek kognitif. Kegiatan pembelajaran ujian TKK wajib kepramukaan dengan menggunakan media video animasi tutorial dilihat pada gambar ini.

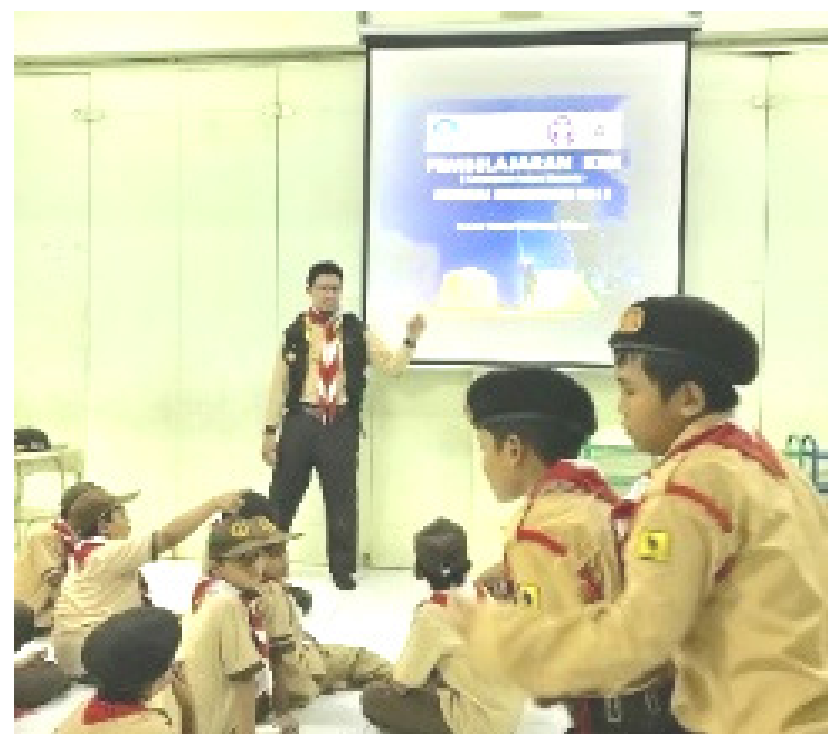

Gambar 3. Kegiatan Pramuka dengan Video Animasi

Dari kegiatan posttest yang peneliti telah lakukan digambarkan dalam tabel di atas ditemukan bahwa ada peningkatan yang drastis dalam pembelajaran sebanyak 28 siswa yang mendapat nilai di atas KKM atau sebesar $94 \%$ dari jumlah siswa sebanyak 32 siswa. Sisanya hanya 4 siswa dinyatakan belum lulus. Adapun gambaran presentase nilai evaluasi posttest dapat dilihat pada diagram berikut.

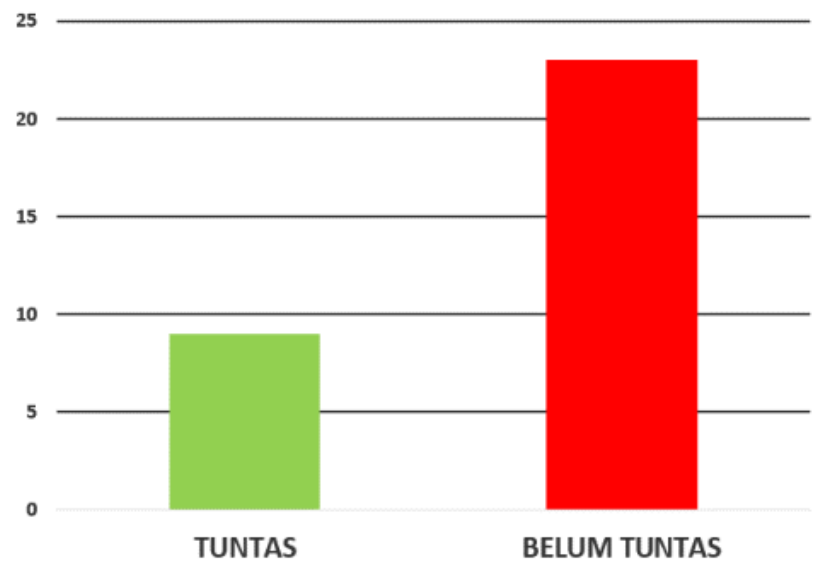

Gambar 4. Diagram Ketuntasan Nilai Post-Test Aspek Kognitif Ujian Pramuka

\section{Pembahasan}

Produk yang dihasilkan dari penelitian pengembangan ini berupa video animasi tutorial ujian TKK wajib pramuka yang hanya terjadi interaksi satu arah atau non-interaktif. Adapun sasaran yang dituju dalam user video animasi tutorial adalah siswa ekstrakurikuler pramuka tingkat penggalang yang akan mengikuti ujian TKK wajib pada tingkatan Sekolah Dasar. Desain penelitian pengembangan yang menjadi acuan peneliti adalah pengembangan 
ADDIE dengan tahap pengembangan: analisis kebutuhan, menyusun kerangka pengembangan video, pengembangan video, uji coba video animasi yang telah dikembangkan, dan evaluasi analisis untuk tahap perbaikan.

Pengujian video dilakukan bertempat di SDIT Ibnu Hajar Mandiri Bekasi pada kegiatan kepramukaan dengan media pembelajaran laptop dan proyektor dalam sebuah ruangan aula dengan panduan dari kakak pembina pramuka tingkat penggalang. Dalam kegiatan ini guru sejawat yang juga bertugas sebagai pembina pramuka juga diminta untuk menilai efisiensi dan efektivitas dalam menggunakan video animasi tutorial ujian TKK wajib pramuka tingkat penggalang bagi siswa SDIT Ibnu Hajar Mandiri Bekasi.

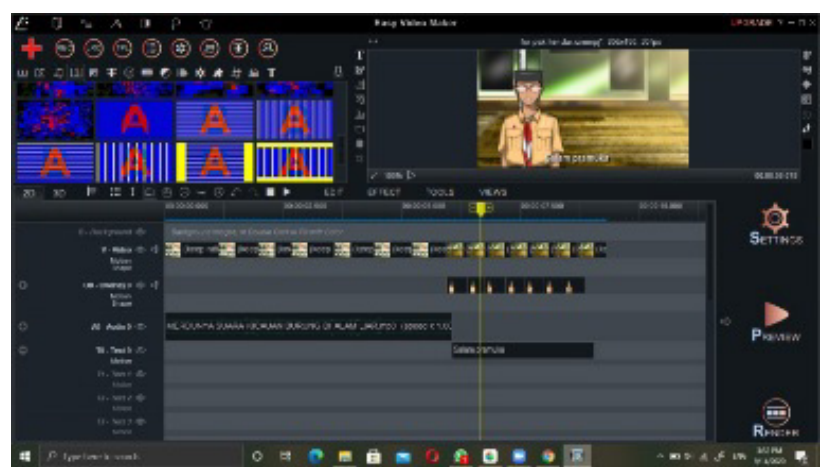

Gambar 5. Tampilan Video Animasi Tutorial Pramuka.

Dari hasil penilaian dari praktisi ahli kepramukaan sebagai pengguna yang dilakukan pada tahap evaluasi media, video animasi tutorial yang telah dikembangkan telah memenuhi syarat sebagai laik untuk digunakan sebagai salah satu sumber belajar pendukung dalam kegiatan ekstrakurikuler pramuka untuk melaksanakan ujian TKK wajib tingkat penggalang pada gugus depan SDIT Ibnu Hajar Mandiri Bekasi.

\section{a. Hasil Penilaian Ahli Media}

Berdasarkan dari penilaian oleh ahli media mengacu kepada beberapa indikator antara lain: 1) tampilan pembukaan video yang menarik; 2 ) isi konten video yang mudah untuk dipahami; 3) visualisasi yang menarik; 4) gambar yang sesuai dengan konten; 5) tulisan dan caption yang jelas; 6) ukuran huruf yang sesuai; 7) gradasi warna yang sesuai; 8) pengunaan ilustrasi yang relevan; 9) layout yang sesuai; 10) daya tarik tampilan video ketika ditampilkan; 11) ketepatan dalam efek suara; 12) ketepatan animasi kakak pembina sebagai presenter; 13) penampilan teknis ujian TKK yang sesuai; 14) narasi yang sesuai; 15) penggunaan bahasa dan dialog yang baik; dan 16) kecukupan durasi video animasi tutorial ujian TKK wajib tingkat penggalang dinilai baik sebagai salah satu media pembelajaran dalam kegiatan pramuka untuk pelaksanaan ujian TKK wajib.

Tabel 8.

Rekapitulasi Hasil Penilaian Uji Kelayakan Ahli Media

\begin{tabular}{lcc}
\hline Aspek Penilaian & $\begin{array}{c}\text { Nilai } \\
\text { Perolehan }\end{array}$ & Keterangan \\
\hline Konten & 4.20 & Baik \\
Desain Video & 4.25 & Baik \\
Tampilan Video & 4.30 & Baik \\
Narasi & 4.20 & Baik \\
Rata-Rata & 4.26 & Baik \\
\hline
\end{tabular}

\section{b. Hasil Penilaian Ahli Materi}

Adapun hasil penilaian dari ahli materi dengan mengacu kepada beberapa indikator yang terdiri atas: 1) kesesuaian video dengan materi ujian TKK pramuka; 2) konsep penyajian video; 3 ) relevansi dengan kurikulum kepramukaan tingkat penggalang yang berlaku; 4) kegiatan kepramukaan yang sesuai dengan tujuan pembelajaran; 5) kesesuaian dengan kompetensi dasar yang telah dirumuskan, 6) penyajian materi, 7) kejelasan dalam menjelaskan materi, 8) refrensi yang digunakan dalam membuat konten.

Tabel 9.

Rekapitulasi Hasil Penilaian Uji Kelayakan Ahli Materi

\begin{tabular}{lcc}
\hline \multicolumn{1}{c}{ Aspek Penilaian } & $\begin{array}{c}\text { Nilai } \\
\text { Perolehan }\end{array}$ & Keterangan \\
\hline $\begin{array}{l}\text { Kesesuaian Tujuan } \\
\text { Instruksional }\end{array}$ & 4.50 & Baik \\
$\begin{array}{l}\text { Tingkat Kedalaman } \\
\text { Materi }\end{array}$ & 4.80 & Baik \\
Penyajian Materi & 4.30 & Baik \\
Rata-Rata & 4.53 & Baik \\
\hline
\end{tabular}

Dari beberapa penilaian ahli yang telah dilakukan, produk media instruksional berupa video animasi tutorial ujian TKK wajib kepramukaan tingkat penggalang dianggap telah memenuhi syarat sebagai salah satu sumber belajar yang digunakan pada kegiatan ekstrakurikuler pramuka untuk pelaksaan ujian TKK wajib.

\section{PENUTUP}

\section{Kesimpulan}

Desain penelitian pengembangan media instruksional video animasi tutorial ujian TKK wajib 
tingkat penggalang dirancang dengan menggunakan model pengembangan ADDIE, dengan tahapan pengembangan (a) analisis kebutuhan untuk menentukan masalah instruksional dan solusi yang tepat serta menentukan kompetensi siswa, (b) menentukan pendekatan dalam kegiatan instruksional, menyususn kerangka pengembangan video animasi tutorial, Garis Besar Isi Media Video (GBIMV), serta penyusunan lembar evaluasi dan penilaian, (c) mengembangkan video animasi tutorial ujian TKK wajib sesuai dengan karakteristik yang sudah ditentukan sebelumnya, (d) Uji coba video animasi telah dikembangkan, melakukan tes dan evaluasi, serta membagi angket respon terkait video animasi yang telah dikembangkan, dan (e) melakukan analisis serta perbaikan terhadap setiap kesalahan yang terjadi dalam proses dan kegiatan instruksional. Pada tahap pengembangan, pengembangan video pembelajaran ini melibatkan beberapa tim pengembang yang dinilai ahli untuk menghasilkan video pembelajaran, selain itu juga peneliti melibatkan ahli materi dan media sebagai penilai kelayakan video animasi tutorial ujian TKK wajib kepramukaan sebagai salah satu media instruksional. Adapun pelaksanan implementasi, penelitiaan ini melibatkan pembina pramuka bersertifikasi KPL (Kursus Pelatih Lanjutan) sebagai penilai kelayakan video animasi tutorial ujian TKK wajib tingkat penggalang sebagai salah satu video instruksional dalam kegiatan kepramukaan di SDIT Ibnu Hajar Mandiri Bekasi.

Nilai yang didapatkan dari hasil pengujian holistik antara ahli materi, ahli media, dan ahli instuksional diperoleh hasil baik, dan media instruksional berupa video animasi tutorial yang telah dikembangkan ini dapat menjadi acuan dari salah satu sumber belajar yang dapat membantu siswa dalam pelaksanaan ujian TKK wajib dalam kegiatan kepramukaan. Dari aspek nilai efektivitas video animasi tutorial ujian TKK wajib kepramukaan tingkat penggalang ini berdasarkan hasil pretest dan posttest yang telah didapatkan adalah bahwa terdapat peningkatan hasil pada tes aspek kognitif pada posttest yang dilakukan dari pretest sebelumnya. Dari hasil aspek kognitif pretest yang hanya sebanyak $30 \%$ dari 32 siswa yang mendapatkan nilai diatas KKM, artinya hanya 9 dari 32 siswa yang mendapatkan nilai diatas KKM. Namun pada kegiatan posttest siswa mengalami peningkatan yang drastis, yaitu sebanyak 28 siswa dinyatakan tuntas mendapatkan nilai ujian TKK wajib penggalang diatas KKM. Hal ini menunjukan bahwa video animasi tutorial ujian TKK wajib kepramukaan dinilai layak sebagai salah satu sumber belajar pada kegiatan pramuka.

\section{Saran}

Dari hasil penelitian tersebut, peneliti memberikan beberapa rekomedasi bedasarkan kegiatan penelitian yang peneliti telah lakukan, beberapa hal yang menurut peneliti penting untuk direkomendasikan diantaranya bahwa pengembangan video pembelajaran berupa animasi tutorial ujian TKK wajib kepramukaan perlu melibatkan beberapa pihak dalam skala besar, diantaranya; ahli materi dari Kwartir Nasional Gerakan Pramuka, ahli media yang memiliki kompetensi dan jam terbang yang lebih berpengalaman, hingga ahli desain instruksional yang ahli sehingga hasil akhir dari video animasi tutorial ini dapat lebih maksimal untuk digunakan dalam skala yang lebih besar.

Selain itu penelitian yang peneliti lakukan masih dalam skala kecil di gugus depan SDIT Ibnu Hajar Mandiri Bekasi dan hanya pada pramuka tingkat penggalang. Sejatinya kegiatan kepramukaan memiliki beberapa golongan, diantaranya; 1) Siaga, 2) Penggalang, 3) Penegak, dan 4) Pandega.

\section{DAFTAR PUSTAKA}

Video Animasi pada Materi Kenampakan Alam dan Sosial Budaya Siswa Kelas IV SDN Ponggok 1 Blitar. Skripsi tidak diterbitkan. Malang: UIN Maulana Malik Ibrahim.

Arikunto, Suharsimi. (2014). Prosedur Penelitian Suatu Pendekatan Praktik. Jakarta: Rineka Cipta.

Branch, Robert M. (2009) The Instructional Design: The ADDIE Approach. New York: Springer.

Damanik, Saipul Ambri. (2014). Pramuka Ekstrakurikuler Wajib di Sekolah. Jurnal Ilmu Keolahragaan Universitas Negeri Medan, 13(2), 16-21.

Hanafri, Muhammad. I.; Rizky, Nur; Yuliyana, Putri \& Muhammad, P. (2018). Rancang Bangun "Tunas Muda Apps" sebagai Media Pembelajaran Pramuka diSDN Cisoka 2. Jurnal Sisfotek Global, 8(2), 67-74.

Heinich, Robert.; Molenda, Michael; Russel, James D.; Smaldino, Sharon E. (1996). Instructional Media and Technologies for Learning ( $\left.5^{\text {th }} \mathrm{ed}\right)$. Englewood Cliffs, NJ: Prentice-Hall, Inc.

Kemendikbud. (2014). Kepramukaan Bahan Ajar Implementasi Kurikulum 2013 Bagi Kepala Sekolah. Jakarta: Pusat Pengembangan Tenaga Kependidikan, Kementerian Pendidikan dan Kebudayaan.

Khasanah, Isnaeni T; Wahyuni. (2013). Media 
Pembelajaran Pramuka Berbasis Multimedia. Skripsi tidak diterbitkan. Bandung: Universitas Komputer Indonesia.

Wahyuni \& Arianto, Asnandar. (2018). “Scout Learning" sebagai Media Interaktif Pembelajaran Pramuka Berbasis Multimedia. Jurnal Teknologi dan Informasi, 7(1), 21-28.

Arifin, Yusuf; Setyosari, Punaji; Ulfa, Saida. (2018). Pengembangan Multimedia Interaktif Materi
Sandi Morse dalam Kegiatan Ekstrakurikuler Kepramukaan Bagi Siswa Kelas V. Jurnal Kajian Teknologi Pendidikan, 1(2), 115-122.

Seels, B. B. and Richey, R. C. (1994). Instructional Technology: The Definition and Domains of the Fields. Washington D.C: AECT.

Sugiyono. (2017). Metode Penelitian dan Pengembangan Research and Development. Bandung: Penerbit Alfabeta. 